DALAT UNIVERSITY JOURNAL OF SCIENCE Volume 9, Issue 2, $2019 \quad 34-48$

\title{
OPTIMIZATION OF EXTRACTION CONDITIONS FOR PHENOLIC COMPOUNDS FROM LEAVES OF CAMELLIA DALATENSIS LUONG, TRAN \& HAKODA
}

\section{Huynh Dinh Dung ${ }^{\mathrm{a}}$, Lu Hoang Truc Linh ${ }^{\mathrm{b}}$, Luong Van Dung ${ }^{\mathrm{b}}$, Nguyen Thi To Uyen ${ }^{\mathrm{a}}$, Trinh Thi Diep ${ }^{\mathrm{a}^{*}}$}

${ }^{a}$ The Faculty of Chemistry, Dalat University, Lamdong, Vietnam

${ }^{b}$ The Faculty of Biology, Dalat University, Lamdong, Vietnam

*Corresponding author: Email: dieptt@dlu.edu.vn

\section{Article history}

Received: November $26^{\text {th }}, 2018$

Received in revised form ( $\left(1^{\text {st }}\right)$ : January $1^{\text {st }}, 2019 \mid$ Received in revised form $\left(2^{\text {nd }}\right)$ : January $17^{\text {th }}, 2019$

Accepted: January $24^{\text {th }}, 2019$

\begin{abstract}
The extraction conditions of polyphenols from Camellia dalatensis leaves were optimized by experimental design with five variables using Design-Expert V11.1.0.1 software. Using the methodology of response surface optimization, the optimal polyphenol extraction conditions were found to be an ethanol concentration of $49.29 \%$, temperature at $60^{\circ} \mathrm{C}, \mathrm{a}$ sonication time of 40min, a material size of $0.5 \mathrm{~mm}$, and a solvent/material ratio of 5.47 .
\end{abstract}

Keywords: Camellia dalatensis; Optimization of extraction; Polyphenol extraction; Response surface methodology.

DOI: http://dx.doi.org/10.37569/DalatUniversity.9.2.530(2019)

Article type: (peer-reviewed) Full-length research article

Copyright () 2019 The author(s).

Licensing: This article is licensed under a CC BY-NC-ND 4.0 


\section{TỐI U'U HÓA ĐIỀU KIỆN CHIẾT XUẤT HợP CHẤT PHENOL TÙ LÁ TRÀ ĐÀ LẠT CAMELLIA DALATENSIS LUONG, TRAN \& HAKODA}

\section{Huỳnh Đình Dũnga ${ }^{a}$ Lữ Hoàng Trúc Linh ${ }^{b}$, Lương Văn Dũng ${ }^{b}$, Nguyễn Thị Tố Uyên ${ }^{\mathrm{a}}$, Trịnh Thị Điệp ${ }^{\mathrm{a}^{*}}$}

${ }^{a}$ Khoa Hóa học, Trưòng Đại học Đà Lạt, Lâm Đồng, Việt Nam

${ }^{b}$ Khoa Sinh học, Trường Đại học Đà Lạt, Lâm Đồng, Việt Nam

"Tác giả liên hệ: Email: dieptt@dlu.edu.vn

\section{Lịch sử bài báo}

Nhận ngày 26 tháng 11 năm 2018

Chỉnh sửa lần 01 ngày 01 tháng 01 năm 2019 | Chỉnh sửa lần 02 ngày 17 tháng 01 năm 2019

Chấp nhận đăng ngày 24 tháng 01 năm 2019

\section{Tóm tắt}

Các điều kiện chiết xuất polyphenol tù̀ lá Trà mi Đà Lạt (C. dalatensis) đã được tối uu hóa bằng phuoong pháp quy hoạch thục nghiệm, sủ dụng phần mềm Design-Expert V11.1.0.1. Qua phuơng pháp tôi uu hóa bằng đáp ưng bề mặt, các điều kiện chiết xuất polyphenol tối uu đã được xác định là: Dung môi chiết cồn $49.29 \%$, nhiệt độ chiết $60^{\circ} \mathrm{C}$, thời gian siêu âm 40 phút, kích thước nguyên liệu $0.5 \mathrm{~mm}$, và tỷ lệ dung môi/nguyên liệu 5.47.

Từ khóa: Camellia dalatensis; Chiết xuất Polyphenol; Phương pháp đáp ứng bề mặt; Tối ưu hóa chiết xuất.

DOI: http://dx.doi.org/10.37569/DalatUniversity.9.2.530(2019)

Loại bài báo: Bài báo nghiên cứu gốc có bình duyệt

Bản quyền @ 2019 (Các) Tác giả.

Cấp phép: Bài báo này được cấp phép theo CC BY-NC-ND 4.0 


\section{INTRODUCTION}

Polyphenolic compounds comprise a group of biologically active molecules. Plant polyphenols are used to prevent chronic diseases, such as neurodegenerative disorders, cardiovascular diseases, type II diabetes, osteoporosis, and cancer (Scalbert, Manach, Morand, Remesy, \& Jimenez, 2005). One of the rich sources of polyphenols is green tea (Camellia sinensis), a type of drink that has been used for thousands of years. Recent studies on green tea show that tea polyphenols have many beneficial effects on human health, such as: Antioxidant, cholesterol-lowering, anti-inflammatory, antibacterial, antiviral, anti-cancer, and antidiabetic effects (Fu et al., 2017; Higdon \& Frei, 2003; Maron et al., 2003; \& Rafieian \& Movahedi, 2017). The predominant source of tea polyphenols are catechins, such as: Epicatechin (EC), -epicatechin-3-gallate (ECG), epigallocatechin (EGC), and epigallocatechin-3-gallate EGCG) (Higdon \& Frei, 2003; Kanwar et al., 2012; \& Maron et al., 2003).

Dalat tea (Camellia dalatensis Luong, Tran \& Hakoda) is an endemic tea species of Dalat, recently discovered and named by Tran and Luong (2012). Through a preliminary investigation of chemical composition, we found that Dalat tea leaves contain relatively high levels of total polyphenols (Tran, Lu, Tran, Luong, \& Trinh, 2017). Polyphenol extraction from green tea and other plant materials has been much studied. The common processes used for extraction of tea polyphenol include conventional solvent extraction, ultrasound assisted extraction (UAE), microwave assisted extraction, high hydrostatic pressure, and supercritical fluid extraction (Chang, Chiu, Chen, \& Chang, 2000; Jun et al., 2009; Jun et al., 2010; Nkhili et al., 2009; \& Xia, Shi, \& Wan, 2006). Since ancient times, the traditional approach of hot water extraction has been the main technique to extract polyphenols. In 2000, soxhlet extraction, or extraction with $95 \%$ ethanol, was regarded as the best method for total polyphenol extraction (Chang et al., 2000). But such traditional methods are very timeconsuming and require relatively large quantities of solvents, which not only escalate the cost of production, but also negatively affect the environment during disposal. UAE is a preferred mode of tea polyphenol extraction due to the fact that it can be performedat low temperature which avoids thermo-sensitive degradation of the active biomolecules (Su, Duan, Jiang, Shi, \& Kakuda, 2006; Xia et al., 2006). UAE works based mainly on the mechanism known as spreading of ultrasound pressure waves within the medium followed by formation of cavitation bubble. Due to the limitations of bubble expansion, they implode and microturbulence is hence created, which disrupts cell membranes, enhances biomass permeability, and accelerates solvent dissolution of the target substance (Vilkhu, Mawson, Simons, \& Bates, 2008). The polyphenol extraction efficiency of UAE is influenced by several parameters, such as the chemical nature of the sample, extraction time, extraction temperature, type and concentration of solvent, and sample/solvent ratio (Sharmila et al., 2016; Xia et al., 2006).

In order to achieve higher extraction yields, a model is required for the optimization of the most relevant parameters. A mathematical technique, response surface methodology (RSM), is an effective tool to find the optimal conditions for the process when many parameters and their interactions may affect the desired response. 
The RSM technique is applied to optimize the extraction conditions of the phenolic content obtained from several plant materials (Klanian \& Preciat, 2017; Nour, Trandafir, \& Cosmulescu, 2016; Rajaei, Barzegar, Hamidi, \& Sahari, 2010; \& Saci, Louaileche, Bachirbey, \& Meziant, 2016). Therefore, the current study was carried out to optimize the polyphenol extraction from Dalat tea leaves by utilizing the methodology of response surface to provide a scientific basis for development of a healthy product from this local source of polyphenols.

\section{MATERIALS AND METHODS}

\subsection{Plant materials and chemicals}

The leaves of $C$. dalatensis were collected in Tramhanh, Dalat city in January, 2018 and identified by biologist Luong Van Dung, the faculty of Biology, Dalat University. After collecting, the leaves were packed in sealed plastic bags, stored in a refrigerator at $5^{\circ} \mathrm{C}$, and then ground to the desired sizes. A voucher specimen has been deposited at the Natural Product Lab, the Faculty of Chemistry, Dalat University.

\subsection{Methods}

\subsubsection{Experimental design}

The effects of five dependent variables on polyphenol extraction were evaluated using RSM (Anderson \& Whitcomb, 2017) onthe Design-Expert V11.1.0.1 software of State-Ease lnc., Minneapolis, MN, USA (Table 1).

Table 1. The RSM model applied in the study

\begin{tabular}{|c|c|c|c|c|}
\hline File version & 11.1.0.1 & & & \\
\hline Study type & Response surface & & Subtype & Randomized \\
\hline Design type & I-optimal & Coordinate exchange & Runs & 85 \\
\hline Design model & Reduced quadratic & & Blocks & No blocks \\
\hline Build time (ms) & 9033.00 & & & \\
\hline
\end{tabular}

The main factors influencing the effectiveness of extraction, including ethanol concentration $(\%, \mathrm{~A})$, extraction temperature $\left({ }^{\circ} \mathrm{C}, \mathrm{B}\right)$, sonication time (min, C), material size $(\mathrm{mm}, \mathrm{D})$, and solvent/material ratio $(\mathrm{mL} / \mathrm{g}, \mathrm{E})$ were selected as independent variables. The ranges of values for the variables were chosen on the base of a preliminary experiment, taking into account the limits of the ultrasonic device. Table 2 presents the coded values of the experimental factors for the design. The complete design followed a random order process and contained 85 combinations (Table 3). Design-Expert V11.1.0.1 software was used to perform statistical analysis. Experimental data were fitted to a second-order polynomial model in which multiple 
regression analysis and variance analysis were used to determine goodness of fit the model and optimal extraction conditions for the investigated studied responses.

Table 2. Independent variables and their coded and actual values used for optimization

\begin{tabular}{llllllll}
\hline Factor & Name & Units & Type & Minimum & Maximum & Coded low & Coded high \\
\hline A & Ethanol concentration & $\%$ & Numeric & 30.0 & 90.0 & $-1.0 \leftrightarrow 30.0$ & $+1.0 \leftrightarrow 90.0$ \\
B & Sonication time & min & Numeric & 10.0 & 40.0 & $-1.0 \leftrightarrow 10.0$ & $+1.0 \leftrightarrow 40.0$ \\
C & Extraction temperature & ${ }^{\circ} \mathrm{C}$ & Numeric & 30.0 & 60.0 & $-1.0 \leftrightarrow 30.0$ & $+1.0 \leftrightarrow 60.0$ \\
D & Material size & $\mathrm{mm}$ & Numeric & 0.5 & 1.0 & $-1.0 \leftrightarrow 0.5$ & $+1.0 \leftrightarrow 1.0$ \\
$\mathrm{E}$ & Solvent/material ratio & $\mathrm{mL} / \mathrm{g}$ & Numeric & 3.0 & 6.0 & $-1.0 \leftrightarrow 3.0$ & $+1.0 \leftrightarrow 6.0$ \\
\hline
\end{tabular}

\subsubsection{Polyphenol extraction}

Four grams of sample material were put in a capped Erlenmeyer flask $(100 \mathrm{~mL})$ and mixed with ethanol-water. The process of extraction was performed in an ultrasonic bath (Elma - Xtra $30 \mathrm{H}$ Elmasonic, $35 \mathrm{kHz}, 400 \mathrm{~W}$ ) at a constant temperature. After this extraction, the extracted substance was filtered through (Whatman No.1 paper) then the filtrate was then gathered in a volumetric flask and used for determining the total polyphenol content.

\subsubsection{Determination of total polyphenol content}

Total polyphenol content (TPC) in the extracts was determined by a colorimetric method according to TCVN 9745-1:2013 using Folin-Ciocalteu reagent (Merck) (Ministry of Science and Technology, 2013a). Gallic acid (monohydrate, purity 98.0\%, HiMedia Labs, India) was used as the polyphenol standard. Briefly, $1.0 \mathrm{~mL}$ of sample solution was mixed with $5 \mathrm{~mL}$ diluted Folin - Ciocalteu reagent $(10 \%$, v/v). After 5 minutes of incubation at room temperature without light, $4 \mathrm{~mL}$ of aqueous $\mathrm{Na}_{2} \mathrm{CO}_{3}$ $(7.5 \%, \mathrm{w} / \mathrm{v})$ was put into the mix. After gentle vibration, the mixture was kept at room temperature for $60 \mathrm{~min}$. Absorbance was measured at $765 \mathrm{~nm}$ using a UV-vis spectrophotometer (Spekol, 2000). Total polyphenol content was expressed as grams gallic acid equivalents per 100 grams of dried leaves (\%).

Moisture content of the leaves was determined by using weight loss on drying in an oven at $105^{\circ} \mathrm{C}$ for four hours (Ministry of Science and Technology, 2013b). 


\section{RESULTS AND DISCUSSION}

\subsection{Fitting the models of response surface}

Table 3. Design arrangement for extraction and the responses of polyphenols

$\begin{array}{lllllllllllll}\text { A } & \text { B } & \text { C } & \text { D } & \text { E } & \text { TPC } & & \text { A } & \text { B } & \text { C } & \text { D } & \text { E } & \text { TPC }\end{array}$

$\begin{array}{llllllllllllll}\text { Run } & (\%) & (\mathrm{min}) & \left({ }^{\circ} \mathrm{C}\right) & (\mathrm{mm}) & (\mathrm{mL} / \mathrm{g}) & (\%) & \text { Run } & (\%) & (\mathrm{min}) & \left({ }^{\circ} \mathrm{C}\right) & (\mathrm{mm}) & (\mathrm{mL} / \mathrm{g}) & (\%)\end{array}$

\begin{tabular}{|c|c|c|c|c|c|c|c|c|c|c|c|c|c|}
\hline 1 & 50 & 20 & 50 & 0.5 & 6 & 27.95 & 44 & 30 & 30 & 60 & 0.5 & 4 & 27.95 \\
\hline 2 & 30 & 10 & 30 & 1.0 & 6 & 21.03 & 45 & 30 & 30 & 30 & 1.0 & 4 & 22.28 \\
\hline 3 & 90 & 10 & 60 & 1.0 & 6 & 24.80 & 46 & 90 & 10 & 30 & 0.5 & 3 & 22.54 \\
\hline 4 & 70 & 20 & 40 & 0.5 & 4 & 26.06 & 47 & 30 & 20 & 40 & 1.0 & 5 & 22.41 \\
\hline 5 & 70 & 10 & 50 & 0.5 & 4 & 26.19 & 48 & 50 & 30 & 30 & 0.5 & 5 & 24.42 \\
\hline 6 & 50 & 40 & 40 & 0.5 & 5 & 29.84 & 49 & 90 & 40 & 50 & 0.5 & 5 & 25.31 \\
\hline 7 & 70 & 30 & 60 & 1.0 & 5 & 26.82 & 50 & 70 & 10 & 40 & 0.5 & 6 & 25.68 \\
\hline 8 & 90 & 10 & 40 & 0.5 & 3 & 22.79 & 51 & 50 & 40 & 60 & 0.5 & 6 & 28.58 \\
\hline 9 & 50 & 10 & 60 & 1.0 & 6 & 28.70 & 52 & 50 & 40 & 30 & 0.5 & 5 & 28.07 \\
\hline 10 & 50 & 20 & 40 & 1.0 & 3 & 24.68 & 53 & 90 & 30 & 60 & 1.0 & 4 & 21.53 \\
\hline 11 & 90 & 10 & 40 & 1.0 & 3 & 22.41 & 54 & 50 & 30 & 40 & 0.5 & 5 & 26.56 \\
\hline 12 & 70 & 40 & 40 & 0.5 & 3 & 25.56 & 55 & 50 & 40 & 30 & 1.0 & 3 & 23.92 \\
\hline 13 & 90 & 20 & 40 & 1.0 & 5 & 24.42 & 56 & 70 & 10 & 30 & 0.5 & 3 & 23.54 \\
\hline 14 & 70 & 20 & 50 & 1.0 & 5 & 26.31 & 57 & 90 & 30 & 60 & 0.5 & 5 & 24.42 \\
\hline 15 & 30 & 30 & 60 & 0.5 & 6 & 27.32 & 58 & 90 & 30 & 30 & 0.5 & 4 & 23.29 \\
\hline 16 & 70 & 40 & 50 & 0.5 & 6 & 25.43 & 59 & 30 & 20 & 50 & 1.0 & 6 & 24.55 \\
\hline 17 & 50 & 40 & 40 & 1.0 & 5 & 28.20 & 60 & 90 & 40 & 30 & 0.5 & 3 & 23.67 \\
\hline 18 & 30 & 10 & 40 & 1.0 & 4 & 21.78 & 61 & 70 & 30 & 40 & 1.0 & 5 & 25.93 \\
\hline 19 & 70 & 10 & 60 & 1.0 & 6 & 27.32 & 62 & 30 & 30 & 40 & 0.5 & 4 & 22.66 \\
\hline
\end{tabular}


Table 3. Design arrangement for extraction and the responses of polyphenols (cont.)

$\begin{array}{lllllllllllll}\text { A } & \text { B } & \text { C } & \text { D } & \text { E } & \text { TPC } & \text { A } & \text { B } & \text { C } & \text { D } & \text { E } & \text { TPC }\end{array}$

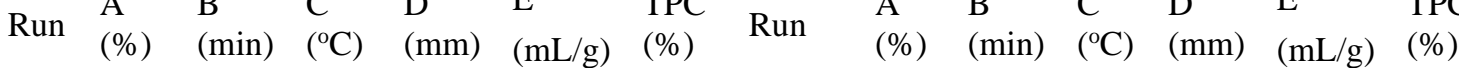

\begin{tabular}{|c|c|c|c|c|c|c|c|c|c|c|c|c|c|}
\hline 20 & 30 & 40 & 30 & 0.5 & 5 & 23.29 & 63 & 30 & 40 & 30 & 1.0 & 5 & 23.67 \\
\hline 21 & 30 & 10 & 50 & 1.0 & 6 & 24.05 & 64 & 50 & 10 & 50 & 0.5 & 5 & 24.73 \\
\hline 22 & 70 & 30 & 50 & 0.5 & 3 & 22.66 & 65 & 50 & 10 & 30 & 1.0 & 3 & 23.29 \\
\hline 23 & 90 & 20 & 60 & 1.0 & 3 & 23.04 & 66 & 50 & 20 & 60 & 1.0 & 6 & 28.83 \\
\hline 24 & 50 & 20 & 60 & 0.5 & 3 & 23.42 & 67 & 30 & 40 & 50 & 0.5 & 6 & 26.56 \\
\hline 25 & 90 & 40 & 40 & 0.5 & 6 & 24.80 & 68 & 30 & 40 & 40 & 1.0 & 5 & 22.54 \\
\hline 26 & 70 & 40 & 30 & 1.0 & 4 & 25.05 & 69 & 50 & 20 & 30 & 0.5 & 3 & 22.41 \\
\hline 27 & 30 & 10 & 40 & 0.5 & 3 & 21.40 & 70 & 90 & 10 & 50 & 1.0 & 4 & 24.55 \\
\hline 28 & 70 & 40 & 60 & 0.5 & 3 & 24.93 & 71 & 90 & 20 & 40 & 0.5 & 4 & 24.05 \\
\hline 29 & 30 & 20 & 50 & 0.5 & 3 & 23.80 & 72 & 90 & 40 & 30 & 1.0 & 6 & 24.05 \\
\hline 30 & 90 & 20 & 30 & 1.0 & 3 & 22.79 & 73 & 70 & 10 & 50 & 1.0 & 4 & 26.19 \\
\hline 31 & 70 & 20 & 60 & 0.5 & 3 & 25.93 & 74 & 70 & 30 & 30 & 0.5 & 6 & 26.19 \\
\hline 32 & 30 & 20 & 30 & 0.5 & 3 & 21.78 & 75 & 50 & 10 & 40 & 0.5 & 4 & 26.31 \\
\hline 33 & 50 & 30 & 60 & 0.5 & 5 & 28.96 & 76 & 70 & 30 & 30 & 1.0 & 4 & 25.18 \\
\hline 34 & 90 & 30 & 40 & 1.0 & 4 & 22.54 & 77 & 30 & 40 & 60 & 1.0 & 6 & 27.45 \\
\hline 35 & 50 & 30 & 40 & 1.0 & 6 & 26.06 & 78 & 50 & 40 & 50 & 0.5 & 4 & 28.70 \\
\hline 36 & 50 & 30 & 30 & 1.0 & 3 & 23.17 & 79 & 70 & 20 & 50 & 0.5 & 6 & 27.07 \\
\hline 37 & 90 & 20 & 50 & 0.5 & 5 & 25.05 & 80 & 30 & 40 & 40 & 0.5 & 4 & 23.67 \\
\hline 38 & 90 & 30 & 50 & 1.0 & 5 & 24.93 & 81 & 90 & 40 & 60 & 1.0 & 4 & 24.42 \\
\hline 39 & 30 & 10 & 60 & 0.5 & 6 & 26.69 & 82 & 30 & 20 & 60 & 1.0 & 6 & 26.82 \\
\hline
\end{tabular}


Table 3. Design arrangement for extraction and the responses of polyphenols (cont.)

\begin{tabular}{llllllllllllll}
\hline Run & $\begin{array}{l}\mathrm{A} \\
(\%)\end{array}$ & $\begin{array}{l}\mathrm{B} \\
(\mathrm{min})\end{array}$ & $\begin{array}{l}\mathrm{C} \\
\left({ }^{\circ} \mathrm{C}\right)\end{array}$ & $\begin{array}{l}\mathrm{D} \\
(\mathrm{mm})\end{array}$ & $\begin{array}{l}\mathrm{E} \\
(\mathrm{mL} / \mathrm{g})\end{array}$ & $\begin{array}{l}\mathrm{TPC} \\
(\%)\end{array}$ & Run & $\begin{array}{l}\mathrm{A} \\
(\%)\end{array}$ & $\begin{array}{l}\mathrm{B} \\
(\mathrm{min})\end{array}$ & $\begin{array}{l}\mathrm{C} \\
\left({ }^{\circ} \mathrm{C}\right)\end{array}$ & $\begin{array}{l}\mathrm{D} \\
(\mathrm{mm})\end{array}$ & $\begin{array}{l}\mathrm{E} \\
(\mathrm{mL} / \mathrm{g})\end{array}$ & $\begin{array}{l}\mathrm{TPC} \\
(\%)\end{array}$ \\
\hline 40 & 70 & 20 & 30 & 1.0 & 5 & 25.81 & 83 & 50 & 30 & 50 & 1.0 & 4 & 27.45 \\
41 & 70 & 10 & 40 & 1.0 & 3 & 22.16 & 84 & 30 & 30 & 50 & 0.5 & 3 & 23.67 \\
42 & 50 & 40 & 50 & 1.0 & 6 & 27.70 & 85 & 90 & 30 & 50 & 0.5 & 5 & 24.93 \\
43 & 90 & 20 & 60 & 0.5 & 6 & 25.18 & & & & & & \\
\hline
\end{tabular}

Table 3 shows that polyphenol compounds extracted from $C$. dalatensis leaves ranged from $21.03 \%$ to $29.84 \%$. A second-order polynomial model demonstrating the relationship between polyphenols yield (TPC, \%) and the five independent variables in the study was obtained in Equation (1).

$T P C(\%)=26.60-0.11 A+0.45 B+1.11 C-0.17 D+1.00 E-0.46 A B-1.18 A C$ $+0.036 A D+0.16 A E-0.20 B C-0.13 B D-0.007 B E+0.12 C D+0.31 C E-0.047 D E-$ $2.37 A^{2}+0.24 B^{2}+0.15 C^{2}-0.99 E^{2}$

The fitness and significance of the design were then determined using an analysis of variance (ANOVA, Table 4). The model F-value of 9.89 and p-value < 0.0001 in Table 4 indicate the model is significant. The Lack-of-Fit f-value of 1.02 and $\mathrm{p}=0.5632$ indicate the Lack-of-Fit is not significant in relation to pure error. Additionally, the degree of freedom for evaluation of lack of fit is 60, much higher than the recommended minimum of 3 for ensuring the model validation. The Predicted $\mathrm{R}^{2}$ of 0.6895 (Table 5) was in reasonable agreement with the Adjusted $\mathrm{R}^{2}$ of 0.7529 ; i.e., the difference was less than 0.2. Adeq precision measures the signal-to-noise ratio. A ratio greater than 4 is desirable (Anderson \& Whitcomb, 2017). Our ratio of 17.1482 indicates an adequate signal. This model can be used to navigate the design space.

Table 4. Analysis of variance (ANOVA) for the investigated models

\begin{tabular}{lcccccc}
\hline Source & $\begin{array}{l}\text { Sum of } \\
\text { squares }\end{array}$ & Df* & $\begin{array}{l}\text { Mean } \\
\text { square }\end{array}$ & f-value & p-value & \\
\hline Model & 270.4100 & 19 & 14.2300 & 9.8900 & $<0.0001$ & significant \\
A-Ethanol concentration & 37.3500 & 1 & 37.3500 & 25.9500 & $<0.0001$ & \\
B-Sonication time & 1.9800 & 1 & 1.9800 & 1.3800 & 0.2447 & \\
C-Extraction temperature & 17.2600 & 1 & 17.2600 & 11.9900 & 0.0010 & \\
\hline
\end{tabular}


Table 4. Analysis of variance (ANOVA) for the investigated models (cont.)

\begin{tabular}{|c|c|c|c|c|c|c|}
\hline Source & $\begin{array}{l}\text { Sum of } \\
\text { squares }\end{array}$ & Df* & $\begin{array}{l}\text { Mean } \\
\text { square }\end{array}$ & f-value & $\mathrm{p}$-value & Note \\
\hline D-Material size & 3.0000 & 1 & 3.0000 & 2.0800 & 0.1536 & \\
\hline E-Solvent/material ratio & 39.6800 & 1 & 39.6800 & 27.5700 & $<0.0001$ & \\
\hline $\mathrm{AB}$ & 8.2700 & 1 & 8.2700 & 5.7400 & 0.0194 & \\
\hline $\mathrm{AC}$ & 27.4400 & 1 & 27.4400 & 19.0600 & $<0.0001$ & \\
\hline $\mathrm{AD}$ & 0.0490 & 1 & 0.0490 & 0.0340 & 0.8542 & \\
\hline $\mathrm{AE}$ & 0.7196 & 1 & 0.7196 & 0.4998 & 0.4821 & \\
\hline $\mathrm{BC}$ & 0.2141 & 1 & 0.2141 & 0.1487 & 0.7010 & \\
\hline $\mathrm{BD}$ & 1.6400 & 1 & 1.6400 & 1.1400 & 0.2898 & \\
\hline $\mathrm{BE}$ & 1.1000 & 1 & 1.1000 & 0.7630 & 0.3856 & \\
\hline $\mathrm{CD}$ & 0.1671 & 1 & 0.1671 & 0.1161 & 0.7344 & \\
\hline $\mathrm{CE}$ & 0.1701 & 1 & 0.1701 & 0.1182 & 0.7321 & \\
\hline $\mathrm{DE}$ & 1.1400 & 1 & 1.1400 & 0.7919 & 0.3768 & \\
\hline $\mathrm{A}^{2}$ & 66.7500 & 1 & 66.7500 & 46.3600 & $<0.0001$ & \\
\hline $\mathrm{B}^{2}$ & 1.8700 & 1 & 1.8700 & 1.3000 & 0.2584 & \\
\hline $\mathrm{C}^{2}$ & 0.0436 & 1 & 0.0436 & 0.0303 & 0.8623 & \\
\hline $\mathrm{E}^{2}$ & 7.3800 & 1 & 7.3800 & 5.1300 & 0.0269 & \\
\hline Residual & 93.5800 & 65 & 1.4400 & & & \\
\hline Lack-of-Fit & 86.5000 & 60 & 1.4400 & 1.0200 & 0.5632 & not significant \\
\hline Pure error & 7.0700 & 5 & 1.4100 & & & \\
\hline Cor total & 363.9800 & 84 & & & & \\
\hline
\end{tabular}

Note: *Df: Degree of freedom. 


\section{Table 5. Fit statistics of the model with experiment}

\begin{tabular}{lclc}
\hline Std. Dev. & 1.03 & R-squared & 0.8088 \\
Mean & 24.98 & Adj R-squared & 0.7529 \\
C.V. \% & 4.14 & Pred R-squared & 0.6895 \\
& & Adeq precision & 17.1482 \\
\hline
\end{tabular}

Thus, the ANOVA showed that the regression equation fitted well with the experimental data and the reduced quadratic regression model was proven fit to accurately predict the variation.

\subsection{Diagnostics of the statistical properties of the model}

The results of comparisons of externally studentized Residuals vs. Predicted (a), Residuals vs. Run (b), and Predicted values of TPC and experimental values of TPC (c) are presented in Figure 1, which shows that all the runs were within the red control limits.

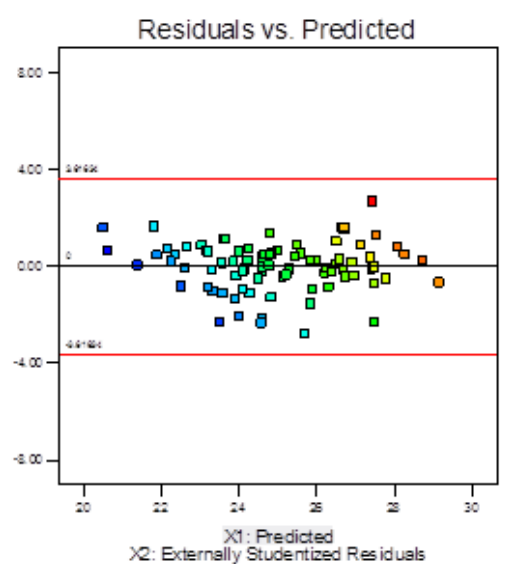

(a)

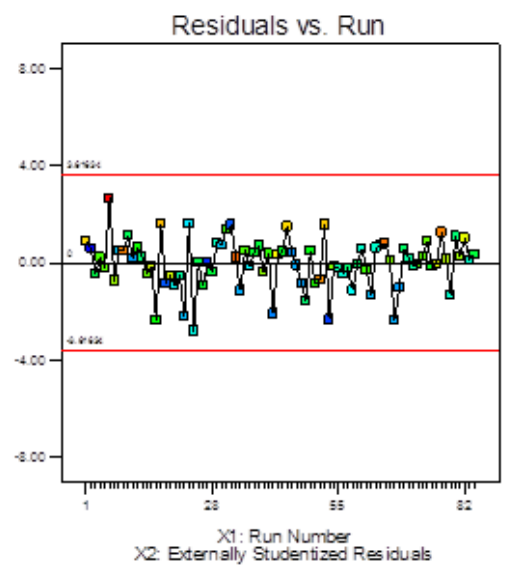

(b)

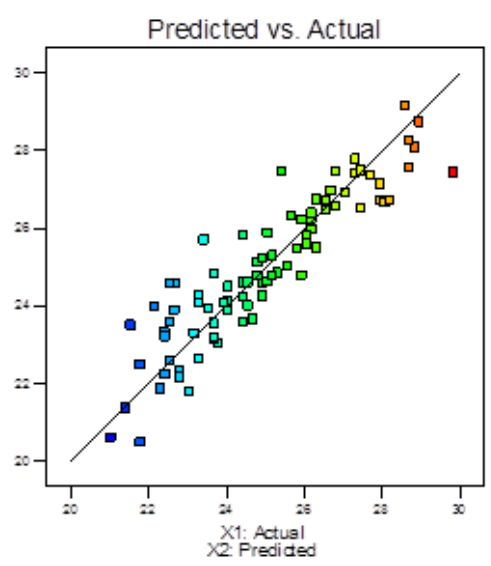

(c)

Figure 1. Comparison of externally studentized Residuals vs. Predicted (a), Residuals vs. Run (b), and Predicted and experimental values (c) for the response variable

\subsection{Effect of extraction parameters on polyphenols}

An ANOVA for the independent variables shown in Table 4 indicated that ethanol concentration $\left(\mathrm{A}, \mathrm{A}^{2}, \mathrm{p}<0.0001\right)$ and solvent/material ratio $\left(\mathrm{E}, \mathrm{p}<0.0001, \mathrm{E}^{2}<\right.$ $0.05)$ were the most significant factors affecting polyphenol extraction yield, followed by extraction temperature $(\mathrm{C}, \mathrm{p}=0.001)$. On the other hand, the sonication time $(\mathrm{B}, \mathrm{p}=$ 0.2447 ) and the material size (factor $D, p=0.1536$ ) seemed to have the least effect on polyphenol extraction yield. This may be because ultrasonic waves could easily break 
down the cell membranes of fresh leaf tissues of any size. The material size also was regarded as an insignificant factor and not included as an investigation factor in some researches on optimization of polyphenol extraction from carob pulps (Saci et al., 2017), pistachio (Rajaei et al., 2010), and Brosimum alicastrum leaves (Klanian \& Preciat, 2017).

By considering the regression coefficients obtained for independent and dependent variables, ethanol concentration, temperature, and solvent/material ratio were the most important factors that may significantly influence TPC. The relationship between independent and dependent variables is illustrated in three dimensional representations of the response surfaces and two-dimensional contour plots generated by the models for TPC (Figures 2a, 2b, \& 2c).

This suggested that solvent concentration plays a critical role in the extraction of phenolic compounds from Camellia leaves. Higher extraction yield of total polyphenols was observed to correlate with higher temperature. This may be due to the various impacts of temperature on mass-transfer processes, such as enhanced diffusivity, leaf matrix degradationand improvement of solvent characteristics regarding polyphenol penetration and solubility. The results from our study are in good agreewith Ghitescu et al. (2015). Moreover, it is a common concern that high temperature extraction often leads to degradation of polyphenols, but in this experimental design we limited the extration temperature to $60^{\circ} \mathrm{C}$. This corresponds with the research by Xia et al. (2006) who found that ultrasonic extraction only decreased tea polyphenol yield above $65^{\circ} \mathrm{C}$.
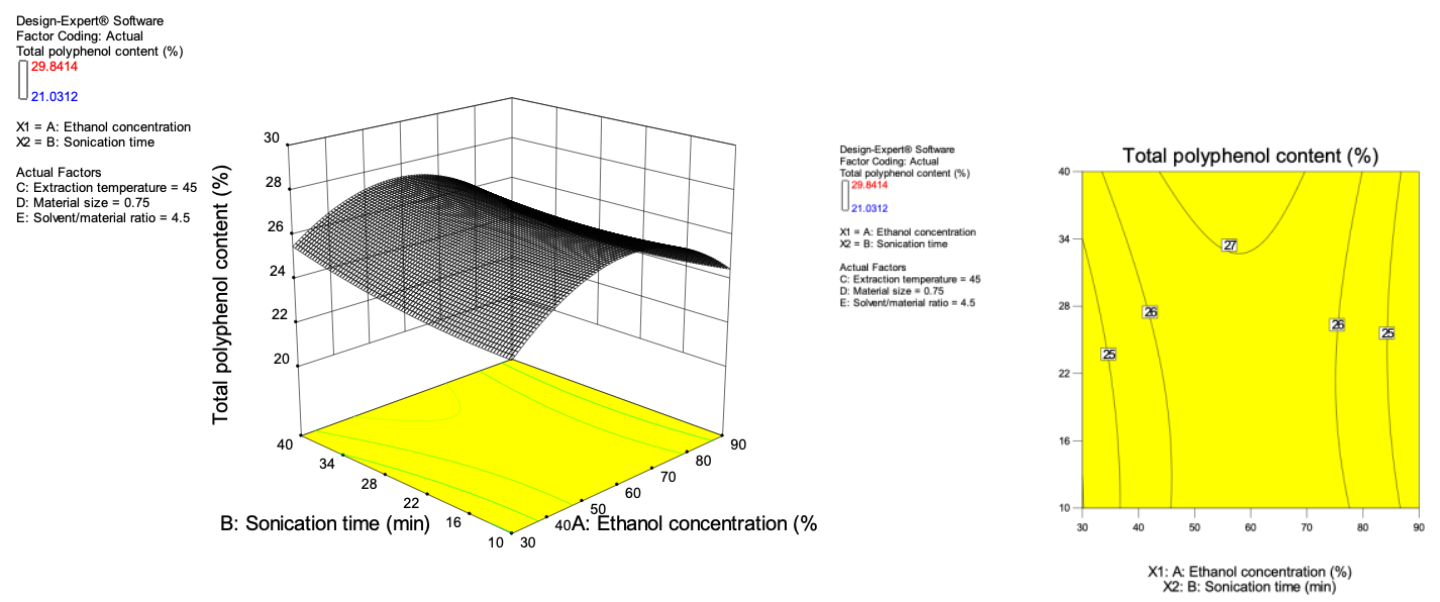

Figure 2a. Response surface and contour plots for TPC as a function of ethanol concentration and sonication time 

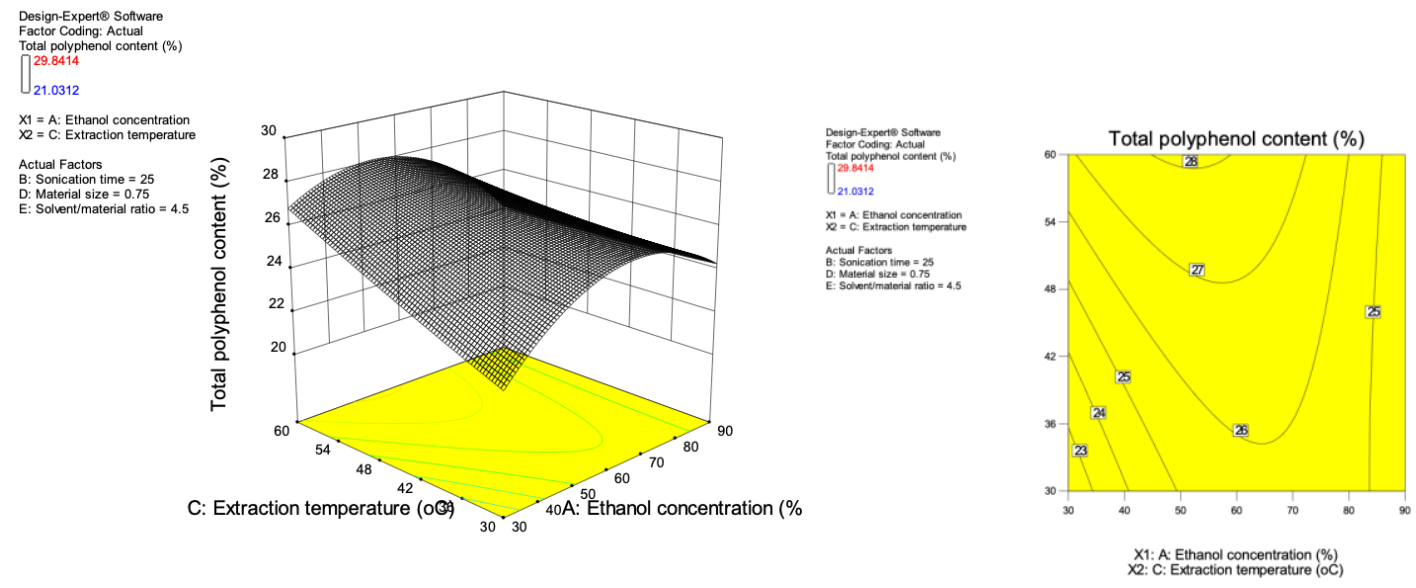

Figure $2 \mathrm{~b}$. Response surface and contour plots for TPC as a function of ethanol concentration and extraction temperature
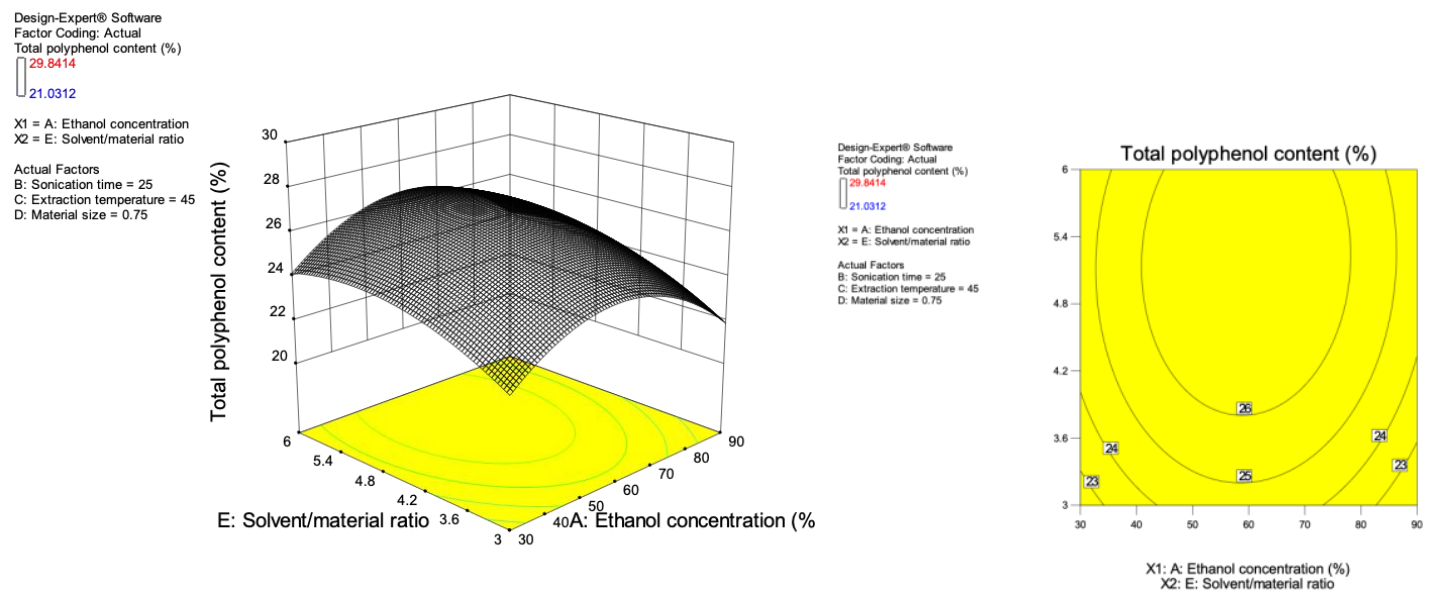

Figure 2c. Response surface and contour plots for TPC as a function of ethanol concentration and solvent/material ratio

\subsection{Extraction conditions optimization and model verification}

The model suggested 100 solutions that predicted polyphenol yields of $28.50 \%$ to $29.30 \%$. The suggested values for the five factors were as follows:

- $\quad$ Ethanol concentration: 42.64 - 55.99\%;

- $\quad$ Sonication time: 27.52 - 40.00min;

- $\quad$ Extraction temperature: $57.44-60.00^{\circ} \mathrm{C}$;

- $\quad$ Material size: $0.50-1.00 \mathrm{~mm}$;

- $\quad$ Solvent/material ratio: $4.47-6.00 \mathrm{~mL} / \mathrm{g}$. 
The maximum polyphenol yield $(29.30 \%)$ was predicted at the optimum conditions, which involved an ethanol concentration of $49.29 \%$, an extraction temperature of $60^{\circ} \mathrm{C}$, a sonication time of 40 minutes, a material size of $0.5 \mathrm{~mm}$, and a solvent $/$ material ratio of $5.47 \mathrm{~mL} / \mathrm{g}$, respectively. Playing the role of the most significant factor affecting polyphenol extraction yield, the optimal solvent concentration found in our study was in agreement with the findings by other researchers who selected the ethanol concentration of 50\% for extraction of tea polyphenols (Jun et al., 2009; Liang, Liang, Dong, \& Lu, 2007).

With the new found optimal conditions applied inthree parallel experiments, polyphenol extraction yield achieved $28.89 \pm 0.51 \%$, which amounting to $98.60 \%$ of the prediction from theoretical model. This result demonstrates that the optimized model suitably explains the actual polyphenol extraction process.

\section{CONCLUSIONS}

The optimal extraction conditions for polyphenols from $C$. dalatensis leaves were analysed using response surface methodology. The effects of ethanol concentration $(30-90 \%)$, extraction temperature $\left(30-60^{\circ} \mathrm{C}\right)$, sonication time $(10-40 \mathrm{~min})$, material size $(0.5-1.0 \mathrm{~mm})$, and solvent/material ratio $(3.0-6.0 \mathrm{~mL} / \mathrm{g})$ were investigated. A second order polynomial model produced a satisfactory fit of the experimental data with regard to total phenolic content $(\mathrm{P}<0.0001)$. The optimal polyphenol extraction conditions were found to be an ethanol concentration of $49.29 \%$, the temperature for extraction at $60^{\circ} \mathrm{C}$, a sonication time of 40 minutes, a material size of $0.5 \mathrm{~mm}$ and a solvent/material ratio of $5.47 \mathrm{~mL} / \mathrm{g}$.

\section{REFERENCES}

Anderson, M. J., \& Whitcomb, P. J. (2017). RSM simplified: Optimizing processes using response surface methods for design of experiments ( $2^{\text {nd }}$ ed.). New York, USA: Taylor \& Francis Group.

Chang, C. J., Chiu, K. L., Chen, Y. L., \& Chang, C. Y. (2000). Separation of catechins from green tea using carbon dioxide extraction. Food Chemistry, 68(1), 109-113.

Fu, Q. Y., Li, Q. S., Lin, X. M., Qiao, R. Y., Yang, R., Li, X. M., Dong, Z. B., Xiang, L. P., Zheng, X. Q., Lu, J. L., Yuan, C. B., Ye, J. H., \& Liang, Y. R. (2017). Antidiabetic effects of tea. Molecules, 22(5), 1-19.

Ghitescu, R. E., Volf, I., Carausu, C., Bühlmann, A. M., Gilca, I. A., \& Popa, V. I. (2015). Optimization of ultrasound-assisted extraction of polyphenols from spruce wood bark. Ultrasonics Sonochemistry, 22, 535-541.

Higdon, J. V., \& Frei, B. (2003). Tea catechins and polyphenols: Health effects, metabolism, and antioxidant functions. Critical Reviews in Food Science and Nutrition, 43(1), 89-143. 
Jun, X., Deji, S., Shou, Z., Bingbing, L., Ye, L., \& Rui, Z. (2009). Characterization of polyphenols from green tea leaves using a high hydrostatic pressure extraction. International Journal of Pharmaceutics, 382(1-2), 139-143.

Jun, X., Shuo, Z., Bingbing, L., Rui, Z., Ye, L., Deji, S., \& Guofeng, Z. (2010). Separation of major catechins from green tea by ultrahigh pressure extraction. International Journal of Pharmaceutics, 386(1-2), 229-231.

Kanwar, J., Taskeen, M., Mohammad, I., Huo, C., Chan, T. H., \& Dou, Q. P. (2012). Recent advances on tea polyphenols. Frontiers in Bioscience, 4, 111-131.

Klanian, M. G., \& Preciat, M. T. (2017). Optimization of the ultrasound-assisted extraction of phenolic compounds from Brosimum alicastrum leaves and the evaluation of their radical-scavenging activity. Molecules, 22(8), 12-19.

Liang, H., Liang, Y., Dong, J., \& Lu, J. (2007). Tea extraction methods in relation to control of epimerization of tea catechins. Journal of the Science of Food and Agriculture, 87(9), 1748-1752.

Maron, D. J., Lu, G. P., Cai, N. S., Wu, Z. G., Li, Y. H., Chen, H., Zhu, J. Q., Jin, X. J., Wouters, B. C., \& Zhao, J. (2003). Cholesterol-lowering effect of a theaflavinenriched green tea extract: A randomized controlled trial. The Archives of Internal Medicine, 163(12), 1448-1453.

Ministry of Science and Technology. (2013a). Tea - Preparation of ground sample of known dry matter content. Retrieved from http://tieuchuan.mard.gov.vn/ Documents/Uploads/TCVN\%209745-1-2013.doc.

Ministry of Science and Technology. (2013b). Determination of substances characteristic of green and black tea. Retrieved from https://vanbanphapluat.co/ tcvn-9738-2013-che-chuan-bi-mau-nghien-xac-dinh-ham-luong-chat-kho.

Nkhili, E., Tomao, V., Hajji, H. E., Boustani, E. S. E., Chemat, F., \& Danglesb, O. (2009). Microwave-assisted water extraction of green tea polyphenols. Phytochemical Analysis, 20(5), 408-415.

Nour, V., Trandafir, I., \& Cosmulescu, S. (2016). Optimization of ultrasound-assisted hydroalcoholic extraction of phenolic compounds from walnut leaves using response surface methodology. Pharmaceutical Biology, 54, 2176-2187.

Rafieian, K. M., \& Movahedi, M. (2017). Breast cancer chemopreventive and chemotherapeutic effects of Camellia sinensis (green tea): An updated review. Electron Physician, 9(2), 3838-3844.

Rajaei, A., Barzegar, M., Hamidi, Z., \& Sahari, M. A. (2010). Optimization of extraction conditions of phenolic compounds from pistachio (Pistachia vera) green hull through response surface method. Journal of Agricultural Science and Technology, 12, 605-615.

Saci, F., Louaileche, H., Bachirbey, M., \& Meziant, L. (2017). Optimization of phenolic compound recovery and antioxidant activity from carob pulp using response surface methodology. International Food Research Journal, 24(3), 1094-1101. 
Scalbert, A., Manach, C., Morand, C., Remesy, C., \& Jimenez, L. (2005). Dietary polyphenols and the prevention of diseases. Critical Reviews in Food Science and Nutrition, 45(4), 287-306.

Sharmila, G., Nikitha, V., Ilaiyarasi, S., Dhivya, K., Rajasekar, V., Kumar, N. M., Muthukumaran, K., \& Muthukumaran, C. (2016). Ultrasound assisted extraction of total phenolics from Cassia auriculata leaves and evaluation of its antioxidant activities. Industrial Crops and Products, 84, 13-21.

Su, X., Duan, J., Jiang, Y., Shi, J., \& Kakuda, Y. (2006). Effects of soaking conditions on the antioxidant potentials of Oolong tea. Journal of Food Composition and Analysis, 19(4), 348-353.

Tran, N., \& Luong, V. D. (2012). Camellia dalatensis: A new species and precious gene should be conserved. VNU Journal of Science, Natural Sciences and Technology, 28(2S), 34-36.

Tran, T. P. L., Lu, H. T. L., Tran, T. T. P., Luong, V. D., \& Trinh, T. D. (2017). Investigation of chemical composition and evaluation of polyphenol content in leaf samples of Camellia species naturally grown in Lamdong province. Journal of Medicinal Materials, 22(4), 206-209.

Vilkhu, K., Mawson, R., Simons, L., \& Bates, D. (2008). Applications and opportunities for ultrasound assisted extraction in the food industry - A review. Innovative Food Science and Emerging Technologies, 9, 161-169.

Xia, T., Shi, S., \& Wan, X. (2006). Impact of ultrasonic-assisted extraction on the chemical and sensory quality of tea infusion. Journal of Food Engineering, 74(4), 557-560. 